\title{
Natural Dietary and Herbal Products in Anti-Obesity Treatment
}

\author{
Nan-Nong Sun ${ }^{1}$, Tsung-Yen $\mathrm{Wu}^{1}$ and Chi-Fai Chau ${ }^{1,2, *}$ \\ 1 Department of Food Science and Biotechnology, National Chung Hsing University, \\ Taichung 40227, Taiwan; b506096053@gmail.com (N.-N.S.); binging0168@icloud.com (T.-Y.W.) \\ 2 Agricultural Biotechnology Center, National Chung Hsing University, Taichung 40227, Taiwan \\ * Correspondence: chaucf@nchu.edu.tw; Tel.: +886-4-2285-2420; Fax: +886-4-2287-6211
}

Academic Editors: Min-Hsiung Pan and Filomena Conforti

Received: 2 September 2016; Accepted: 7 October 2016; Published: 11 October 2016

\begin{abstract}
The prevalence of overweight and obesity is on the rise around the world. Common comorbidities associated with obesity, particularly diabetes, hypertension, and heart disease have an impact on social and financial systems. Appropriate lifestyle and behavior interventions are still the crucial cornerstone to weight loss success, but maintaining such a healthy lifestyle is extremely challenging. Abundant natural materials have been explored for their obesity treatment potential and widely used to promote the development of anti-obesity products. The weight loss segment is one of the major contributors to the overall revenue of the dietary supplements market. In this review, the anti-obesity effects of different dietary or herbal products, and their active ingredients and mechanisms of action against obesity will be discussed.
\end{abstract}

Keywords: anti-obesity; weight loss; phytochemicals; dietary supplements; mechanism

\section{Introduction}

Obesity and overweight are major contributors to the global burden of chronic diseases and complications, including cardiovascular diseases, diabetes, and cancer. In 2014, it was reported by World Health Organization (WHO) that more than 1.9 billion adults were overweight, and of these over 600 million were obese. Once mainly a concern for higher income countries, overweight and obesity are also on the rise in low and middle income countries, especially in urban areas [1].

There are many different options for obesity treatments, including dietary control, exercise, life-style changes, prescription weight-loss medications, and weight-loss surgeries [2]. According to the "Pharmacological Management of Obesity: An Endocrine Society Clinical Practice (ESCP) Guideline", recommended by the National Heart, Lung, and Blood Institute [3], the most ideal treatment modality for weight loss should be appropriate dietary and lifestyle changes plus moderate-intensity exercise. However, many epidemic and clinical studies have shown that it is a great challenge to maintain long-term lifestyle modification [4]. Obese patients are easily frustrated during the painful and seemingly endless lifestyle changing progression. Providing ways to accelerate weight loss could inspire obese patient's confidence to accomplish their goals and give them more motivation to change their lifestyle behavior.

In 2007, the Nutrition Business Journal showed that the aggregate market value of dietary supplement reached nearly 20 billion dollars in sales for the USA. It was estimated that there was at least a 700 million dollars market for weight loss products alone in 2008 [5]. By the end of 2015, the global dietary supplements market is estimated to reach nearly 123 billion dollars. In terms of the market segmentation by application, the weight loss segment is one of the major contributors to the overall revenue of the dietary supplements market. The development of the weight loss segment is anticipated to register a compound annual growth rate of 7.4\% over the forecast period 2015-2025 [6]. 
Thus, natural supplements products primarily helping consumers to fight the battle against obesity have been widely explored. A variety of natural plants (e.g., herbs, fruits, and vegetables), functional fatty acids (e.g., polyunsaturated fatty acids and conjugated fatty acids), and other natural dietary compounds have been used in different anti-obesity products. Natural plant products are expected to be potential ingredients for the development of nature-sourced anti-obesity products in the weight loss segment due to rising consumer health awareness. In this study, the anti-obesity effects of different dietary or herbal products, and their active ingredients and mechanisms of action against obesity will be discussed.

\section{Development of Anti-Obesity Drugs}

Anti-obesity drugs have been studied profoundly for decades. The need for adjunctive therapies for weight loss has accelerated the progress in the pharmaceutical industry worldwide. In USA, four FDA-approved oral weight loss drugs have been developed, including orlistat (marketed as Alli and Xenical), Contrave (naltrexone hydrochloride and bupropion hydrochloride extended-release tablets), Belviq (lorcaserin hydrochloride), and Qsymia (phentermine and topiramate extended-release). These clinical medications manipulate body weight by increasing energy expenditure, suppressing appetite, or inhibiting pancreatic lipase to decrease lipid absorption in the intestine $[7,8]$.

Weight loss drugs may appear to be a solution to obesity. However, possible side effects or adverse drug reactions are always a big public health concern and also a major barrier to the development of new drug products. For example, in 1997, two weight loss drugs, fenfluramine (part of the popular fen-phen) and dexfenfluramine (Redux), were withdrawn from the market because of their possible detrimental effects to heart valves. In 2010, sibutramine (Meridia) was also withdrawn due to an increased risk of heart attacks and strokes. In the same year, in response to the occasional reports of severe liver injury with the use of weight loss drug "Xenical", FDA approved a revised drug label in which safety information about its potential side-effect was noticed.

As mentioned in the ESCP Guideline, pharmacological obesity treatment should be intended only for patients with BMI $>30$ or BMI $\geq 27$ with comorbidity [3]. Considering the potential side effects, anti-obesity drugs should be prescribed for obesity only if the benefits of the treatment outweigh the risks.

In face of the adverse side effects of synthetic drugs, natural products are now preferably used due to their effectiveness in managing overweight and many other chronic disorders. For example, traditional herbal medicines with a long history of use along with other natural substances might suppress appetite and promote weight loss. It was in general believed that these natural materials could be relatively more economical with little to no toxic side effects when compared with the synthetic ones [2].

\section{Anti-Obesity Mechanisms of Natural Dietary or Herbal Products}

\subsection{Increase in Energy Expenditure}

Excessive adiposity can primarily be attributed to an imbalance in energy homeostasis, in which the consequences of excessive food intake are not balanced by increased energy expenditure [9]. That is the reason why increasing energy expenditures to build a negative energy balance is crucial to weight management. Energy expenditure can be briefly classified into three categories: (1) physical activity; (2) obligatory energy expenditure; and (3) adaptive thermogenesis. Most anti-obesity products usually regulate body weight through an increase of obligatory energy expenditure. In the human body, the function of brown adipose tissue is to transfer energy from food into heat. Uncoupling protein 1 (also known as thermogenin) in brown adipose tissue plays a key role in thermogenic effect. Therefore, a material capable of upregulating uncoupling protein 1 gene expression could be a potential strategy for achieving an anti-obesity effect by increasing energy expenditure [10]. 


\subsection{Appetite Suppressant Effect}

There has been a rise in satiety-enhancing products on sale in the food supplement marketplace. The biological mechanisms of appetite and satiety are regulated by a complex interaction of neurological and hormonal signals. Many studies have revealed that some food ingredients could provide satiety enhancing effects and be beneficial for weight control [11]. The mechanism underlying the enhanced satiety includes an increase of noradrenaline level and subsequent activation of sympathetic nervous system activity, leading to an increase in satiety and energy expenditure, suppression of hunger, and also elevation in fat oxidation [12].

A line of evidence indicates that neural signal peptides like serotonin, histamine, dopamine, and their associated receptor activities are associated with satiety regulation. These neural signal peptides and their receptors could be potential target areas for the development of supplement products that treat obesity through energy intake reduction by increasing satiety [13].

\subsection{Lipase Inhibitory Effect}

One of the promising strategies for treating obesity is to interfere with fat absorption along the gastrointestinal tract directly (without altering the central nervous system). There has been long-standing interest in discovering and developing inhibitors for nutrient digestion and absorption. The underlying concept is that for any dietary fat being absorbed in human intestine, the fat should be broken down enzymatically by the action of pancreatic lipase. Pancreatic lipase activity is therefore widely considered as one of the most important indicators for the determination of the anti-obesity potential of natural products [14].

As a key enzyme in dietary triglyceride absorption, pancreatic lipase hydrolyzes triglyceride to monoglyceride and fatty acids. Some substances have been confirmed to have capabilities to interact directly with intestinal lipases themselves. One well known example is tetrahydrolipstatin (orlistat), a derivative of the naturally-occurring lipase inhibitor isolated from Streptomyces toxytricini [15]. It is a synthetic drug designed to act through a covalent bond to the active site serine of pancreatic lipase to block the absorption of dietary fat $[16,17]$.

\subsection{Regulatory Effect on Adipocyte Differentiation}

Adipocytes play a central role in the maintenance of lipid homeostasis and energy balance. They have a particular large capacity to store triglycerides as well as to release free fatty acids in response to changing energy demands. As adipocyte tissue growth is associated with both the hyperplasia and hypertrophy of adipocytes, this has led to the development of natural products in anti-obesity therapy that specifically target adipogenesis inhibition. Some research has also suggested that adipocyte differentiation could be inhibited by the blockade of several transcription factors such as C/EBP $\beta$ (CCAAT/enhancer binding protein beta) and PPAR $\gamma$ (peroxisome proliferator-activated receptor gamma) [18]. A study on the inhibitory activity of Sibiraea angustata extracts on adipocyte differentiation has also revealed that the expression of both C/EBP $\beta$ and PPAR $\gamma$ were significantly inhibited leading to a decrease in the lipid content of adipocyte cells [19].

\subsection{Regulatory Effect on Lipid Metabolism}

An increase in the rate of lipolysis stimulates triglyceride hydrolysis and hence diminishes fat storage and combats obesity. The key points to enhance lipolysis have been discussed in many studies. For instance, activation of $\beta$-adrenergic receptor initiatively triggered lipolysis in white adipocytes and non-shivering thermogenesis in brown fat [20]. An activation of adenosine monophosphate-activated protein kinase (AMPK) leading to the increase of fatty acid oxidation and glucose transport in skeletal muscle was another example [21,22]. Hence, transcription factors that can simulate lipolysis become an important feature in the development of anti-obesity products. It has been shown that flavonoids, specifically flavonols (e.g., quercetin), could activate lipoxygenase and attenuate adipogenesis through 
the up-regulation of the AMPK pathway. Additionally, quercetin activates the apoptotic pathway in mature adipocytes through suppression of phosphorylation effect of signal-regulated kinases 1 and 2 (ERK1/2) and c-Jun N-terminal kinase (JNK), both belonging to subfamilies of mitogen-activated protein kinase (MAPK) [23].

\section{Anti-Obesity Products from Natural Resources}

The growing threat of obesity to global health has encouraged scientists and researchers to put more effort into finding an efficient anti-obesity ingredient. Numerous potential materials from natural sources have been investigated along with their active ingredients. These natural materials are mostly derived from plants, including fruits, vegetables, grains, and herbs. The biological benefits of these natural materials are basically contributed by the presence of an abundant amount of phytochemicals, fibers, and unsaturated fatty acids [24]. Some selected natural resources along with their anti-obesity effects and active ingredients are summarized in Table 1, and some notable examples [25-36] will be further discussed.

The anti-obesity products in the market can be classified into three categories: (1) food ingredients; (2) herbal ingredients; and (3) other functional supplements. Developing functional products from what people usually consume in their daily life is probably the most popular segment in the functional supplement industry. Products made from fruits (citrus, and berries), grains (soybean), vegetables, or beverage drinks (tea leaves) are relatively safer and more acceptable to consumers. Nowadays, traditional Chinese medical practitioners use herbal remedies that usually are combinations of different herbs, such as turmeric (Curcuma longa) and mulberry leaf (Morus alba), to treat obese patients. Recently, herbal therapies are not only popular in Asia, but also more and more common in the Western world. This is the reason why herbal materials could be another major category of anti-obesity products [37]. Some other materials, e.g., probiotic and calcium supplements, have also been proven to confer anti-obesity effects.

Previous studies have explored the potential health benefits of fruits. The examples of potential health benefits include anticancer, anti-inflammatory, and anti-obesity effects [38]. Citrus fruit is one of the major categories used for the exploration and exploitation in new anti-obesity products. Phytochemicals including triterpenoids, flavonoids, and alkaloids are candidate ingredients that are found to be abundant in both the peel and pulp of citrus fruits. Cell and animal studies have shown the anti-obesity effects of citrus fruit extracts that help lower body weight gain and white adipose tissue weight. Leptin, which is a key hormone produced by adipocytes and functioning in the regulation of food intake and energy expenditure, was found to be reduced by the intake of citrus fruits. This change in hormonal activity is desirable for the development of citrus-based anti-obesity product. In citrus fruits, methoxylated flavones and flavanone glycosides are the major bioactive flavonoid compounds capable of changing plasma leptin levels.

Anti-obesity products derived from green tea (Camellia sinensis) leaves are also popular in functional food market. The major bioactive ingredients constituent in green tea, accounting for up to $35 \%$ of the dry weight, is polyphenols. They may include flavonols, flavones, and flavan-3-ols (catechins). A number of clinical trials have revealed the beneficial effects of catechins (270 to $1200 \mathrm{mg}$ /day), e.g., reduced body weight, lowered serum leptin levels, and reduced absorption of fatty acid. Another bioactive constituent in tea leaves is caffeine, which influences somatic nervous system activity and acts synergistically with catechins to increase energy expenditure and fat oxidation. Apart from green tea, other herbal tea materials such as maté tea (Ilex paraguariensis), rooibos (Aspalathus linearis), and honeybush (Cyclopia intermedia) have also been studied for their roles in obesity prevention and lipid metabolism [39].

Owing to the wide array of natural products that have potential anti-obesity effects, it is difficult to elaborate on all of them in one study. Scientists are devoted to finding more potential materials. In the world of published studies regarding functional supplements, there seems to be a positive bias. It is worth noting that the doses being studied in many experiments are usually much higher than the actual doses being used in commercial products [5]. 
Table 1. Summary of natural materials and ingredients with potential anti-obesity effects.

\begin{tabular}{|c|c|c|c|c|}
\hline Natural Materials & Bioactive Ingredients & Experimental Details & Major Activities & References \\
\hline $\begin{array}{l}\text { Shiikuwasa } \\
\text { (Citrus depressa) }\end{array}$ & Flavonoids & $\begin{array}{l}\text { 1.0\%-1.5\% methanolic extract; } \\
\text { male ICR mice fed with HFD (fat: } 40 \%, w / w \text { ) for } 4 \text { weeks }\end{array}$ & $\begin{array}{l}10.0 \% \text { reduction in body weight; } \\
50.9 \% \text { reduction in organ WAT weight }\end{array}$ & [25] \\
\hline $\begin{array}{l}\text { Blueberry (Vaccinium ashei) } \\
\text { and Mulberry (Morus australis) }\end{array}$ & Anthocyanins & $\begin{array}{l}\text { mixed juice; male C } 57 \mathrm{BL} / 6 \text { mice fed with HFD } \\
\text { (fat: } 45 \%, w / w) \text { for } 12 \text { weeks }\end{array}$ & $\begin{array}{l}7.30 \%-9.81 \% \text { reduction in body weight; } \\
\text { reduction in WAT adipocyte sizes }\end{array}$ & [26] \\
\hline $\begin{array}{l}\text { Soybean } \\
\text { (Glycine max) }\end{array}$ & Protein isolated & $\begin{array}{l}30 \% \text { protein isolate; } \\
\text { male SD rat fed with HFD (fat: } 25 \%, w / w \text { ) for } 180 \text { days }\end{array}$ & $\begin{array}{l}18.9 \% \text { reduction in body weight gain; } 26.6 \% \\
\text { reduction in body fat; } \\
\text { higher thermogenin expression }\end{array}$ & [27] \\
\hline $\begin{array}{l}\text { Coffee } \\
\text { (Coffea Arabica) }\end{array}$ & Caffeoyl, quinic acids & $\begin{array}{l}0.5 \% \text { to } 1.0 \% \text { aqueous extract; } \\
\text { male C57BL/6J mice fed with HFD (fat: } 30 \%, w / w \text { ) } \\
\text { for } 2-15 \text { weeks }\end{array}$ & $\begin{array}{l}14.3 \% \text { reduction in body weight; } \\
16.2 \% \text { reduction in organ WAT weight; } \\
\text { decrease in liver fat }\end{array}$ & [28] \\
\hline $\begin{array}{l}\text { Green tea } \\
\text { (Camellia sinensis) }\end{array}$ & $\begin{array}{l}\text { Ppolysaccharides, } \\
\text { caffeine and catechins }\end{array}$ & $\begin{array}{l}400 \text { to } 800 \mathrm{mg} / \mathrm{kg} \text { aqueous extract; } \\
\text { male SD rats fed with } \mathrm{HFD} \text { (fat: } 10 \% \text {, } \\
\text { egg yolk powder } 10 \%, w / w \text { ) for } 6 \text { weeks }\end{array}$ & $\begin{array}{l}11.3 \%-16.9 \% \text { reduction in body weight; } \\
\text { reduction in body fat index and WAT } \\
\text { adipocyte sizes }\end{array}$ & [29] \\
\hline $\begin{array}{l}\text { Lotus leaf with taurine } \\
\text { (Nelumbo nucifera) }\end{array}$ & $\begin{array}{l}\text { Alkaloids, flavonoids, } \\
\text { triterpenoids, polyphenols, } \\
\text { steroids, glycosides, and taurine }\end{array}$ & $\begin{array}{l}400 \mathrm{mg} / \mathrm{kg} \text { aqueous extract with taurine; } \\
\text { male SD rats fed with HFD (fat: } 20 \%, w / w) \text { for } 6 \text { weeks }\end{array}$ & $\begin{array}{l}\text { Reduction in body weight; } \\
\text { reduction in WAT adipocyte sizes and number }\end{array}$ & [30] \\
\hline $\begin{array}{l}\text { Ginger } \\
\text { (Zingiber officinale) }\end{array}$ & $\begin{array}{l}\text { Gingerol, paradol, } \\
\text { and shogoal }\end{array}$ & $\begin{array}{l}5 \% \text { ginger powder; } \\
\text { male albino rats fed with HFD (fat: } 30 \%, w / w \text { ) for } 5 \text { weeks }\end{array}$ & $\begin{array}{l}38.6 \% \text { reduction in body weight; } \\
45.7 \% \text { reduction in pancreatic lipase activity }\end{array}$ & [31] \\
\hline $\begin{array}{l}\text { Black wattle } \\
\text { (Acacia mollissima) }\end{array}$ & Robinetinidol and fisetinidol & $\begin{array}{l}5.0 \% \text { aqueous extract; } \\
\text { diabetic KKAy mice fed with HFD (fat: } 60 \%, w / w \text { ) for } 7 \text { weeks }\end{array}$ & $\begin{array}{l}23.2 \% \text { reduction in body weight; } \\
\text { Higher expression of energy } \\
\text { expenditure-related genes }\end{array}$ & [32] \\
\hline $\begin{array}{l}\text { Chili pepper } \\
\text { (Capsicum anпuиm) }\end{array}$ & Capsaicin & $\begin{array}{l}10 \mathrm{mg} / \mathrm{kg} \text { b.w. capsaicin } \\
\text { male SD rats fed with HFD (fat: } 45 \%, w / w \text { ) for } 9 \text { weeks }\end{array}$ & $\begin{array}{l}8 \% \text { reduction in body weight; } \\
\text { reduction in WAT weight and adipocyte sizes }\end{array}$ & [33] \\
\hline $\begin{array}{l}\text { Coptis Root } \\
\text { (Rhizoma coptidis) }\end{array}$ & Berberine & $\begin{array}{l}200 \mathrm{mg} / \mathrm{kg} \text { ethanolic extracts; } \\
\text { male C } 57 \mathrm{BL} / 6 \mathrm{~J} \text { mice fed with HFD (fat: 16.2\%, w/w) for } 6 \\
\text { weeks }\end{array}$ & $\begin{array}{l}\text { Reduction in body weight; } \\
\text { reduction in organ WAT weight }\end{array}$ & [34] \\
\hline $\begin{array}{l}\text { Turmeric } \\
\text { (Curcuma longa) }\end{array}$ & Curcumin & $\begin{array}{l}50 \% \text { ethanolic extract; } \\
\text { male SD rats fed with HFD (fat: } 60 \%, w / w \text { ) for } 12 \text { weeks }\end{array}$ & $\begin{array}{l}15.9 \% \text { reduction in body weight gain; } \\
31.3 \% \text { reduction in organ WAT weight }\end{array}$ & [35] \\
\hline $\begin{array}{l}\text { White mulberry } \\
\text { (Morus alba) }\end{array}$ & $\begin{array}{l}\text { Rutin, resveratrol anthocyanin, } \\
\text { and 1-deoxynojirimycin, }\end{array}$ & $\begin{array}{l}\text { combination of leaves extract }(133-333 \mathrm{mg} / \mathrm{kg}) \text { and fruit extract } \\
(67-167 \mathrm{mg} / \mathrm{kg} \text { ) male C57BL } / 6 \text { mice fed with HFD } \\
\text { (kcal: } 45 \% \text { from fat) for } 12 \text { weeks }\end{array}$ & $\begin{array}{l}53.5 \% \text { reduction in body weight gain; } \\
\text { reduction in organ WAT weight }\end{array}$ & [36] \\
\hline
\end{tabular}

HFD, high fat diet; b.w., body wieght; WAT, white adipose tissue; SD rats, Sprague Dawley rats. 


\section{Functional Ingredients in Natural Anti-Obesity Products}

\subsection{Phytochemicals}

It is well known that the consumption of phytochemicals can have a major contribution to biological effects. The mechanisms of action of phytochemicals include: (1) inhibition of proliferation of precursor cells; (2) increase of apoptosis effect; (3) inhibition of pancreatic lipase activity; and (4) increase in energy expenditure [40]. Some selected phytochemicals that provide anti-obesity effects are briefly described below. A summary of different phytochemicals with anti-obesity effects IS presented in Table 2 [23,41-54].

Table 2. Phytochemicals with anti-obesity effects.

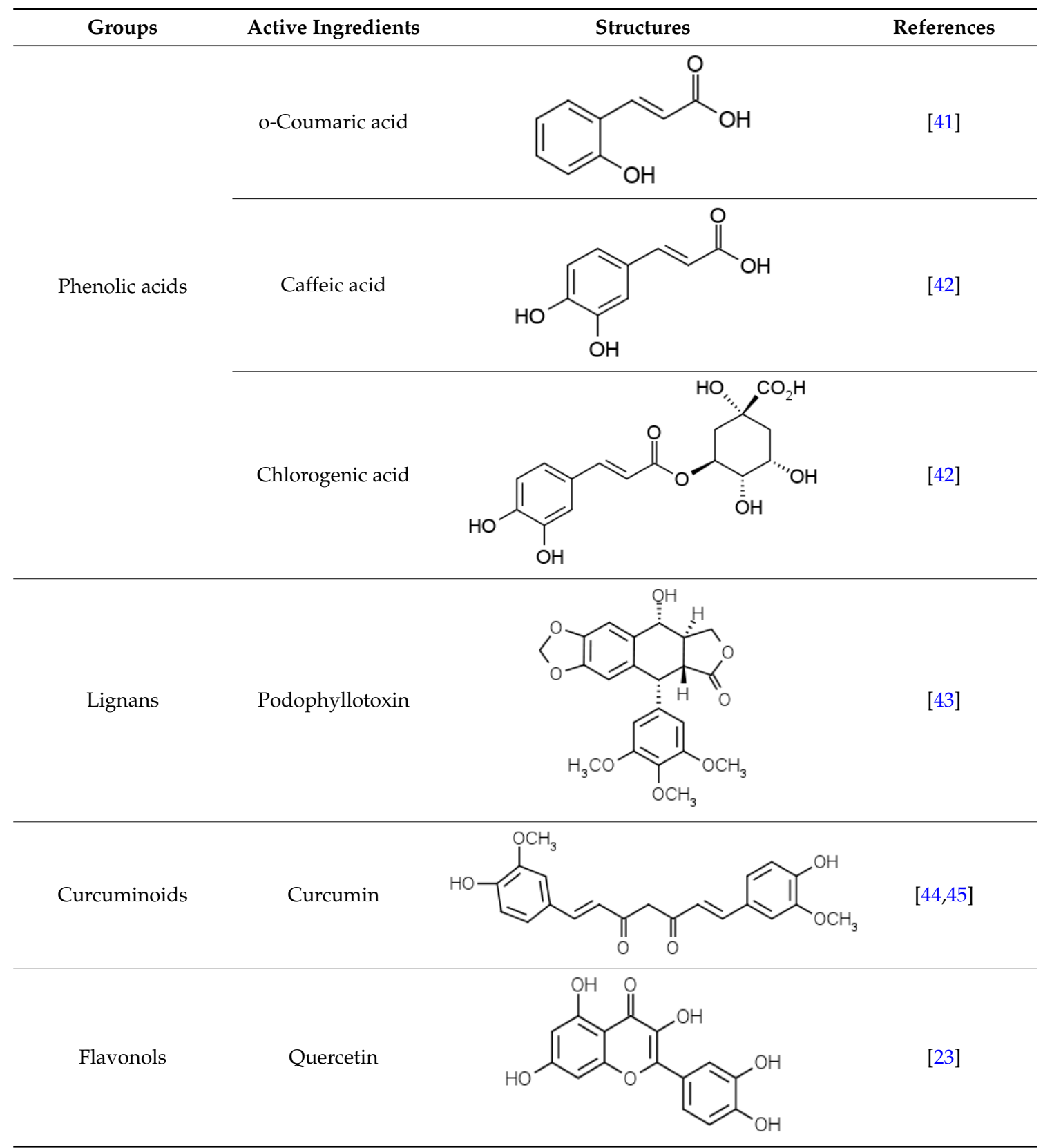


Table 2. Cont.

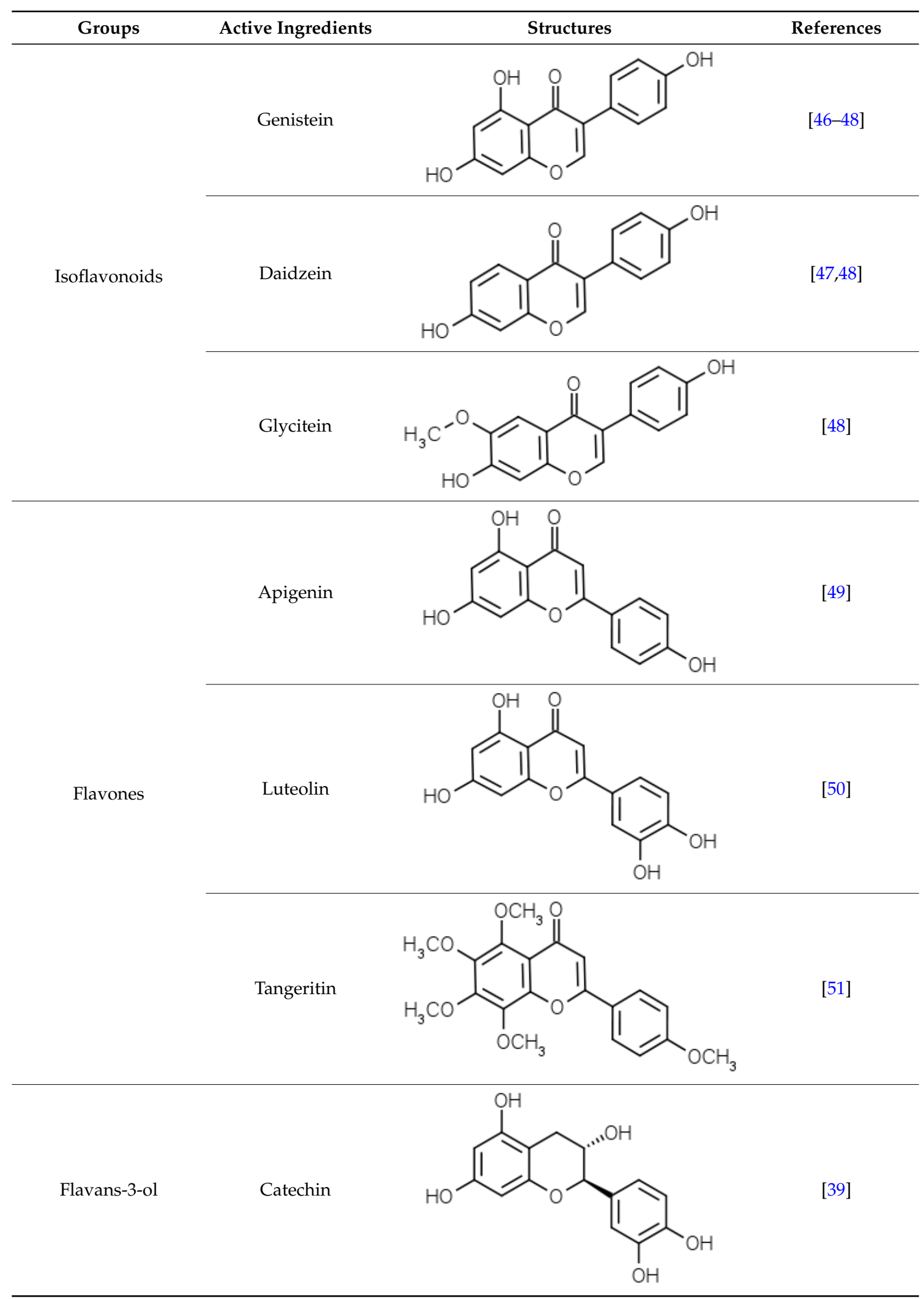


Table 2. Cont

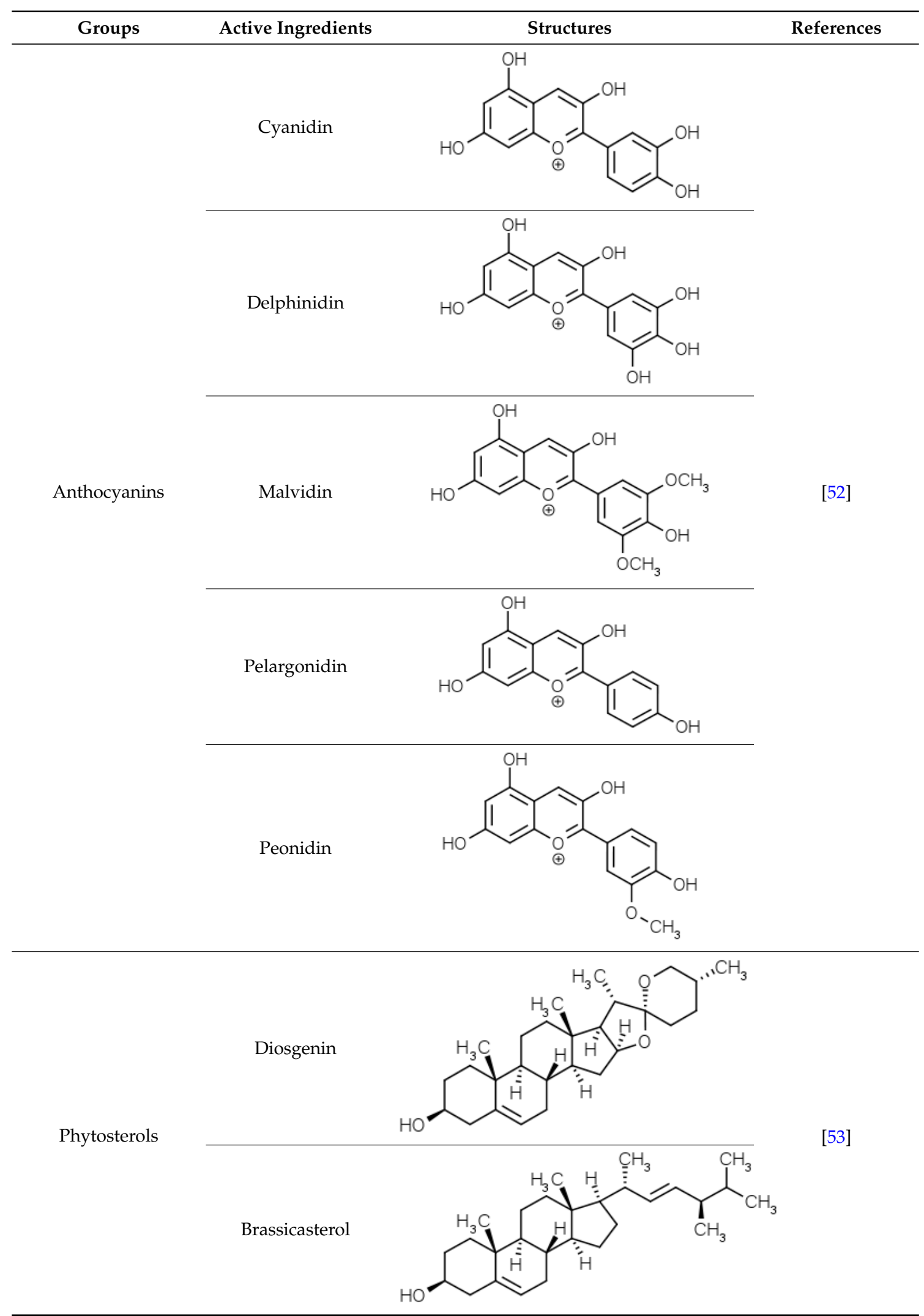


Table 2. Cont.

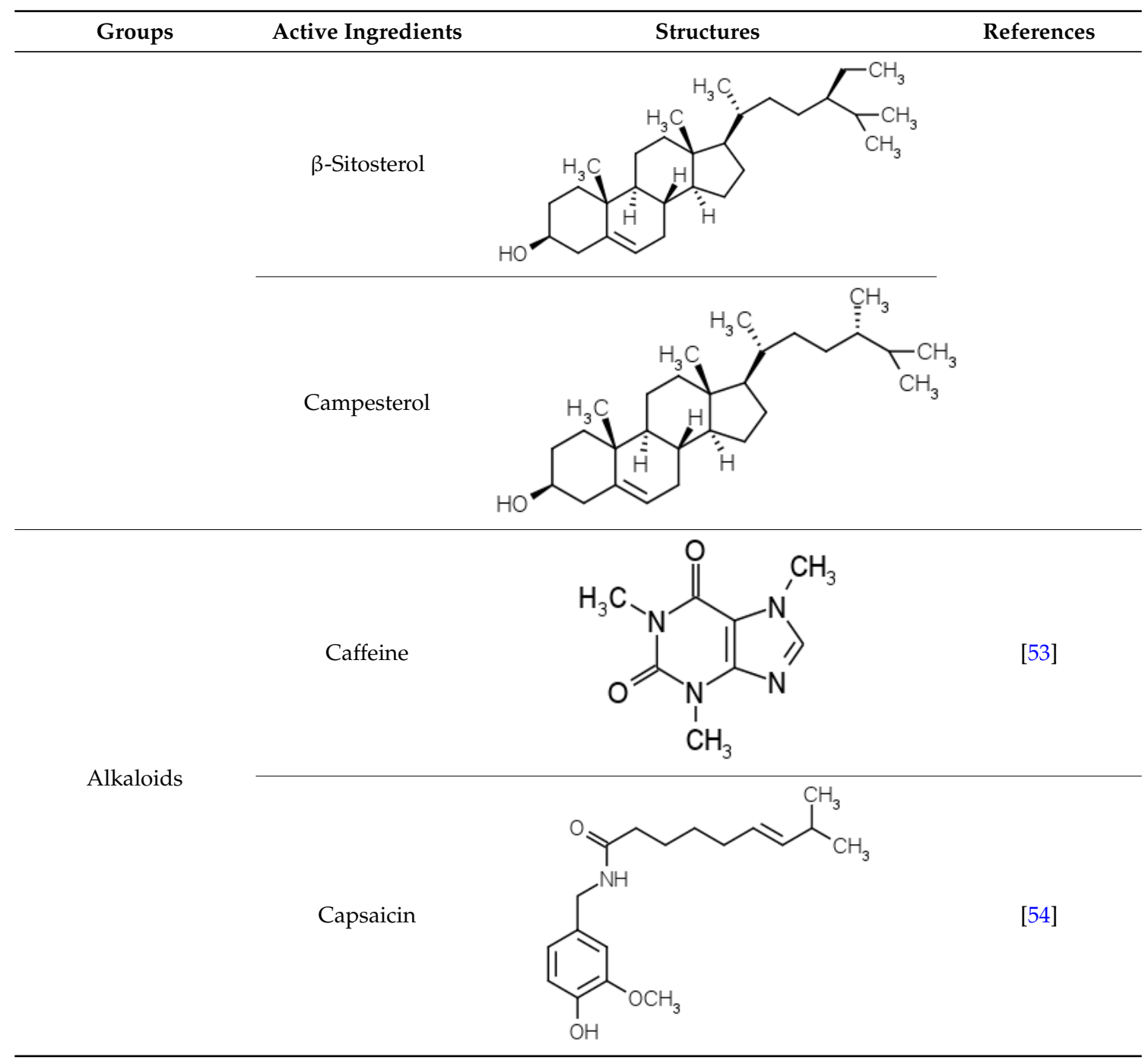

Polyphenols are functional compounds that have anti-carcinogenic, anti-oxidant, anti-bacterial, and anti-viral activities [55]. In the past two decades, polyphenols have also been reported to have beneficial effects against obesity. For example, dietary polyphenols could regulate adipocyte metabolism to inhibit the growth of adipose tissue [56]. Phenolic acids, flavonoids, and stilbenes are the common polyphenols being used in the development of different natural weight management products.

Naturally occurring phenolic acids comprise two classes: hydroxycinnamic acids and hydroxybenzoic acids. Hydroxycinnamic acid derivatives, i.e., coumaric acid, caffeic acid, and ferulic acid, are present mainly in the form of simple esters with glucose or quinic acid. The most commonly occurring acid derivative is chlorogenic acid. In the investigations of dietary phenolic acids on mouse pre-adipocytes, chlorogenic and coumaric acids effectively exerted inhibitory effects on cell growth and enhanced apoptosis. A recent study evaluating the effects of ferulic acid administration on lipid metabolism of mice has found that it could suppress the weight gain due to inhibition of fatty acid biosynthesis [57].

Flavonoids are abundantly present in nature. They have been proven to have the positive effects on anti-obesity. Six subgroups of flavonoids are summarized in Table 2. These include flavonols, flavanones, isoflavonoids, flavones, flavans-3-ol, and anthocyanins. Flavonoids can modulate numbers of cell-signaling pathways to affect carbohydrate digestion, fat deposition, release rate of insulin, and glucose uptake in insulin-responsive tissues. 
Phytosterols, which encompass plant-derived sterols and stanols, are compounds structurally similar to cholesterol. They occur in high concentrations in vegetable oils such as corn, soybean, and sunflower oil [58]. Plant stanols and sterols have been proved capable of blocking the absorption of intestinal fatty acid and reducing body weight gain in animal tests [59].

Alkaloids are generally defined as basic (alkali-like), nitrogen-containing organic constituents commonly found in plants. Alkaloids such as capsaicin and caffeine have been reported to be able to significantly increase energy expenditure, reduce appetite, and inhibit both adipocyte differentiation and pancreatic lipase. Most of these alkaloids are $\alpha$-adrenergic agonists although some of them have $\beta$-adrenergic agonist properties.

\subsection{Polyunsaturated Fatty Acids (PUFAs)}

The potential anti-obesity effects of PUFAs might be explained by their performance in the following aspects: a balance between energy intake and energy expenditure, lipid metabolism, status of adipocytes, and neuroendocrine system [60]. It has been demonstrated that PUFAs could reduce the activity of the key enzymes responsible for lipid synthesis, such as fatty acid synthase and stearoyl-CoA desaturase-1 [61]. Thus, they might avoid free fatty acids entering adipocytes for lipogenesis and also improve lipid oxidation and thermogenesis [62]. Despite large amounts of investigations on the anti-obesity effect of PUFAs, the precise molecular mechanisms underlying the body-fat lowering effects of PUFAs remain largely unknown.

\subsection{Dietary Fiber}

Some anti-obesity products are rich in different types of dietary fiber, such as pectin, gum, cellulose, and soluble dietary fiber. In 1970, Heaton summarized the anti-obesity functions of dietary fiber. He has found that dietary fiber could act like a physiologic obstacle to lower energy intake by three mechanisms: (1) displacement of other nutrients in the diet by dietary fiber; (2) providing satiety and reducing appetite; and (3) inhibiting food absorption in small intestine [63].

Furthermore, recent studies have revealed that viscosity and fermentability are two important physicochemical properties that are closely related to the beneficial physiological effects of dietary fiber [64]. Many soluble dietary fibers (e.g., gums, pectins, and $\beta$-glucans) become thicken while mixing with liquids. Viscosity is a major contributor to physiological effects in the small intestine. An increase in viscosity may present a barrier to slow gastric emptying and delay nutrient absorption. Dietary fiber could also be a fermentable substrate for the colon microbiota, supporting an increase in microbial mass increase and production of short chain fatty acids. A lot of prospective studies have indicated that long-term consumption of fiber-rich diet has a negative correlation with body weight gain [65]. It has almost become a common sense that dietary consumption is crucial in the fight against metabolic disease.

\subsection{Protein}

Many protein supplements such as whey, casein and soy protein have been sold and marketed as an anti-obese product for a long while. Going on a high-protein daily diet could help people lose weight and prevents weight gain rebound [66]. Protein is more satiating than carbohydrate, and is also associated with a greater diet-induced thermogenesis [67]. Previous studies have shown that high-protein intake may induce an increased level of plasma peptide tyrosine-tyrosine which is a key inhibitor of food intake in humans and rodents [68]. The high thermogenesis of protein may be explained by the lack of storage capacity in the body, the high ATP cost of protein synthesis, and the metabolic costs of urea synthesis. It should be noted that the potential anti-obesity effect of any protein supplements could only be exerted in a more efficient manner while being consumed with adequate exercise [69]. 


\subsection{Dietary Calcium}

Dietary calcium is an important factor in the maintenance of skeletal integrity, blood calcium level, and modulation of chronic diseases risks. Several authors have reported that a high intake of calcium may increase fecal fat excretion and energy expenditure [60]. The mechanism of increasing fecal fat excretion is most probably due to the formation of insoluble calcium-fatty acid soaps and/or binding of bile acids [66]. Another study has demonstrated that intracellular calcium plays a key role for regulating adipocyte metabolism. It is supposed that high dose of dietary calcium could modulate circulating calcitriol levels. It in turn decreases intracellular calcium and affects fat metabolism in human adipocytes based on the findings from different cellular studies, animal studies, epidemiological studies, and clinical trials [70]. Nevertheless, some meta-analyses have argued that positive correlation between calcium intake and weight loss might not always be seen [71].

\subsection{Probiotics}

Some studies have provided evidence to support the hypothesis that gut microbes are involved in the development of type 2 diabetes mellitus and obesity [72]. Lipopolysaccharide occurred in the cell wall of gram-negative bacteria (such as Escherichia coli and Enterobacter cloaca B29) might trigger high fat diet-induced obesity [73]. The ability of some probiotics (e.g., Lactobacillus gasseri SBT2055 and Bifidobacterium breve B-3) to decrease body weight and body fat in obese patients has been proven by several clinical studies [74,75]. Mechanisms of action underlying the anti-obesity effects of probiotics include appetite regulation, host metabolism, inhibition of lipid absorption, maintenance of intestinal homeostasis and integrity, and low-grade inflammation have been proposed [76]. Using probiotics or prebiotics in combination would be a better strategy to prevent or alleviate obesity problems.

\section{Conclusions}

Obesity is a complex, chronic disorder caused by an interaction of contributing factors, including dietary, lifestyle, genetic, and environmental factors. Appropriate lifestyle and behavior interventions are the fundamentals of weight loss success, but maintaining such a healthy lifestyle is extremely challenging. The use of some natural anti-obesity products could be considered as a supportive tool to keep obese people holding on their weight-loss goals. It is also possible that the combination of multiple natural products could confer a synergistic activity that increases their anti-obesity action on multiple targets, offering advantages over chemical treatments in terms of serious side-effects. Natural materials may give not only anti-obesity effect but also other health benefits, such as anti-diabetic and anti-hyperlipidemic activities. It is anticipated that the availability of many natural sources will provide a beneficial basis for developing novel anti-obesity products.

Acknowledgments: This work was support by the Ministry of Science and Technology of the Republic of China (MOST 103-2313-B-005-033-MY3) and in part by the Ministry of Education, Taiwan, ROC, under the ATU plan.

Author Contributions: Nan-Nong Sun conducted the primary literature search and drafted the majority of this manuscript. Tsung-Yen Wu provided editorial and technical assistance. Chi-Fai Chau provided expert opinion on literature construction and critically reviewed the manuscript.

Conflicts of Interest: All contributing authors declare no conflicts of interest.

\section{References}

1. WHO. Obesity and Overweight. Available online: http://www.who.int/mediacentre/factsheets/fs311/en/ (accessed on 20 August 2016).

2. Chandrasekaran, C.V.; Vijayalakshmi, M.A.; Prakash, K.; Bansal, V.S.; Meenakshi, J.; Amit, A. Review article: Herbal approach for obesity Management. Am. J. Plant Sci. 2012, 3, 1003-1014. [CrossRef]

3. Apovian, C.M.; Aronne, L.J.; Bessesen, D.H.; McDonnell, M.E.; Murad, M.H.; Pagotto, U.; Ryan, D.H.; Still, C.D. Pharmacological management of obesity: An endocrine society clinical practice guideline. J. Clin. Endocr. Metab. 2015, 100, 342-362. [CrossRef] [PubMed] 
4. Thomas, J.G.; Bond, D.S.; Phelan, S.; Hill, J.O.; Wing, R.R. Weight-loss maintenance for 10 years in the national weight control registry. Am. J. Prev. Med. 2014, 46, 17-23. [CrossRef] [PubMed]

5. Bloomer, R.J.; Canale, R.E.; Blankenship, M.M.; Hammond, K.G.; Fisher-Wellman, K.H.; Schilling, B.K. Effect of the dietary supplement meltdown on catecholamine secretion, markers of lipolysis, and metabolic rate in men and women: A randomized, placebo controlled, cross-over study. Lipids Health Dis. 2009, 8. [CrossRef] [PubMed]

6. Dietary Supplements Market-Driven by Increasing Demand for Health Products: Global Industry Analysis and Opportunity Assessment 2015-2025. Available online: http:/ /www.futuremarketinsights.com/reports/ dietary-supplements-market (accessed on 20 August 2016).

7. Tziomalos, K.; Krassas, G.E.; Tzotzas, T. The use of sibutramine in the management of obesity and related disorders: An update. Vasc. Health Risk Manag. 2009, 5, 441-452. [PubMed]

8. Hursel, R.; Westerterp-Plantenga, M. Thermogenic ingredients and body weight regulation. Int. J. Obes. 2010, 34, 659-669. [CrossRef] [PubMed]

9. Aydin, S. Three new players in energy regulation: Preptin, adropin and irisin. Peptides 2014, 56, 94-110. [CrossRef] [PubMed]

10. Kajimura, S.; Saito, M. A new era in brown adipose tissue biology: Molecular control of brown fat development and energy homeostasis. Annu. Rev. Physiol. 2014, 76, 225-249. [CrossRef] [PubMed]

11. Chambers, L.; McCrickerd, K.; Yeomans, M.R. Optimising foods for satiety. Trends Food Sci. Technol. 2015, 41, 149-160. [CrossRef]

12. Belza, A.; Frandsen, E.; Kondrup, J. Body fat loss achieved by stimulation of thermogenesis by a combination of bioactive food ingredients: A placebo-controlled, double-blind 8-week intervention in obese subjects. Int. J. Obes. 2007, 31, 121-130. [CrossRef] [PubMed]

13. Morton, G.J.; Meek, T.H.; Schwartz, M.W. Neurobiology of food intake in health and disease. Nat. Rev. Neurosci. 2014, 15, 367-378. [CrossRef] [PubMed]

14. Marrelli, M.; Loizzo, M.R.; Nicoletti, M.; Menichini, F.; Conforti, F. Inhibition of key enzymes linked to obesity by preparations from mediterranean dietary plants: Effects on $\alpha$-amylase and pancreatic lipase activities. Plant Foods Hum. Nutr. 2013, 68, 340-346. [CrossRef] [PubMed]

15. Zhu, T.; Wang, L.; Wang, W.; Hu, Z.; Yu, M.; Wang, K.; Cui, Z. Enhanced production of lipstatin from Streptomyces toxytricini by optimizing fermentation conditions and medium. J. Gen. Appl. Microbiol. 2014, 60, 106-111. [CrossRef] [PubMed]

16. Mulzer, M.; Tiegs, B.J.; Wang, Y.; Coates, G.W.; O’Doherty, G.A. Total synthesis of tetrahydrolipstatin and stereoisomers via a highly regio- and diastereoselective carbonylation of epoxyhomoallylic alcohols. J. Am. Chem. Soc. 2014, 136, 10814-10820. [CrossRef] [PubMed]

17. Tsujita, T.; Takaichi, H.; Takaku, T.; Aoyama, S.; Hiraki, J. Antiobesity action of $\epsilon$-polylysine, a potent inhibitor of pancreatic lipase. J. Lipid Res. 2006, 47, 1852-1858. [CrossRef] [PubMed]

18. Kang, H.J.; Seo, H.A.; Go, Y.; Oh, C.J.; Jeoung, N.H.; Park, K.G.; Lee, I.K. Dimethylfumarate suppresses adipogenic differentiation in 3T3-L1 preadipocytes through inhibition of STAT3 activity. PLoS ONE 2013, 8, e61411. [CrossRef] [PubMed]

19. Xiao, L.; Zhang, J.; Li, H.; Liu, J.; He, L.; Zhang, J.; Zhai, Y. Inhibition of adipocyte differentiation and adipogenesis by the traditional chinese herb Sibiraea angustata. Exp. Biol. Med. 2010, 235, 1442-1449. [CrossRef] [PubMed]

20. Bordicchia, M.; Pocognoli, A.; D’Anzeo, M.; Siquini, W.; Minardi, D.; Muzzonigro, G.; Dessì-Fulgheri, P.; Sarzani, R. Nebivolol induces, via $\beta 3$ adrenergic receptor, lipolysis, uncoupling protein 1 , and reduction of lipid droplet size in human adipocytes. J. Hypertens. 2014, 32, 389-396. [CrossRef] [PubMed]

21. Kola, B.; Grossman, A.; Korbonits, M. The role of AMP-activated protein kinase in obesity. Front. Horm. Res. 2008, 36, 198-211. [PubMed]

22. O'Neill, H.M.; Holloway, G.P.; Steinberg, G.R. AMPK regulation of fatty acid metabolism and mitochondrial biogenesis: Implications for obesity. Mol. Cell. Endocrinol. 2013, 366, 135-151. [CrossRef] [PubMed]

23. Ahn, J.; Lee, H.; Kim, S.; Park, J.; Ha, T. The anti-obesity effect of quercetin is mediated by the AMPK and MAPK signaling pathways. Biochem. Biophys. Res. Commun. 2008, 373, 545-549. [CrossRef] [PubMed]

24. Sasidharan, S.; Chen, Y.; Saravanan, D.; Sundram, K.; Latha, L.Y. Extraction, isolation and characterization of bioactive compounds from plants' extracts. Afr. J. Tradit. Complement. Altern. Med. 2011, 8. [CrossRef] 
25. Lee, Y.S.; Cha, B.Y.; Saito, K.; Choi, S.S.; Wang, X.X.; Choi, B.K.; Yonezawa, T.; Teruya, T.; Nagai, K.; Woo, J.T. Effects of a Citrus depressa Hayata (shiikuwasa) extract on obesity in high-fat diet-induced obese mice. Phytomedicine 2011, 18, 648-654. [CrossRef] [PubMed]

26. Wu, T.; Tang, Q.; Gao, Z.; Yu, Z.; Song, H.; Zheng, X.; Chen, W. Blueberry and mulberry juice prevent obesity development in C57BL/ 6 mice. PLoS ONE 2013, 8, e77585. [CrossRef] [PubMed]

27. Torre-Villalvazo, I.; Tovar, A.R.; Ramos-Barragán, V.E.; Cerbón-Cervantes, M.A.; Torres, N. Soy protein ameliorates metabolic abnormalities in liver and adipose tissue of rats fed a high fat diet. J. Nutr. 2008, 138, 462-468. [PubMed]

28. Murase, T.; Misawa, K.; Minegishi, Y.; Aoki, M.; Ominami, H.; Suzuki, Y.; Shibuya, Y.; Hase, T. Coffee polyphenols suppress diet-induced body fat accumulation by downregulating srebp-1c and related molecules in C57BL/6J mice. Am. J. Physiol. Endocrinol. MeTable 2011, 300, E122-E133. [CrossRef] [PubMed]

29. Xu, Y.; Zhang, M.; Wu, T.; Dai, S.; Xu, J.; Zhou, Z. The anti-obesity effect of green tea polysaccharides, polyphenols and caffeine in rats fed with a high-fat diet. Food Funct. 2015, 6, 296-303. [CrossRef] [PubMed]

30. Du, H.; You, J.S.; Zhao, X.; Park, J.Y.; Kim, S.-H.; Chang, K.J. Antiobesity and hypolipidemic effects of lotus leaf hot water extract with taurine supplementation in rats fed a high fat diet. J. Biomed. Sci. 2010, 17. [CrossRef] [PubMed]

31. Mahmoud, R.; Elnour, W. Comparative evaluation of the efficacy of ginger and orlistat on obesity management, pancreatic lipase and liver peroxisomal catalase enzyme in male albino rats. Eur. Rev. Med. Pharmacol. Sci. 2013, 17, 75-83. [PubMed]

32. Ikarashi, N.; Toda, T.; Okaniwa, T.; Ito, K.; Ochiai, W.; Sugiyama, K. Anti-obesity and anti-diabetic effects of acacia polyphenol in obese diabetic KKAy mice fed high-fat diet. J. Evid. Based Complement. Altern. Med. 2011, 2011. [CrossRef] [PubMed]

33. Joo, J.I.; Kim, D.H.; Choi, J.W.; Yun, J.W. Proteomic analysis for antiobesity potential of capsaicin on white adipose tissue in rats fed with a high fat diet. J. Proteome Res. 2010, 9, 2977-2987. [CrossRef] [PubMed]

34. Xie, W.; Gu, D.; Li, J.; Cui, K.; Zhang, Y. Effects and action mechanisms of berberine and rhizoma coptidis on gut microbes and obesity in high-fat diet-fed c57bl/6j mice. PLoS ONE 2011, 6, e24520. [CrossRef] [PubMed]

35. Kim, J.H.; Kim, O.-K.; Yoon, H.G.; Park, J.; You, Y.; Kim, K.; Lee, Y.H.; Choi, K.C.; Lee, J.; Jun, W. Anti-obesity effect of extract from fermented Curcuma longa L. through regulation of adipogenesis and lipolysis pathway in high-fat diet-induced obese rats. Food Nutr. Res. 2016, 60. [CrossRef]

36. Lim, H.H.; Lee, S.O.; Kim, S.Y.; Yang, S.J.; Lim, Y. Anti-inflammatory and antiobesity effects of mulberry leaf and fruit extract on high fat diet-induced obesity. Exp. Biol. Med. 2013. [CrossRef] [PubMed]

37. Park, J.P.; Kim, J.H.; Park, M.K.; Yun, J.W. Potential agents for cancer and obesity treatment with herbal medicines from the green garden. Biotechnol. Bioprocess Eng. 2011, 16, 1065-1076. [CrossRef]

38. Liu, R.H. Health-promoting components of fruits and vegetables in the diet. Adv. Nutr. 2013, 4, 384S-392S. [CrossRef] [PubMed]

39. Rains, T.M.; Agarwal, S.; Maki, K.C. Antiobesity effects of green tea catechins: A mechanistic review. J. Nutr. Biochem. 2011, 22. [CrossRef] [PubMed]

40. Birari, R.B.; Bhutani, K.K. Pancreatic lipase inhibitors from natural sources: Unexplored potential. Drug Discov. Today 2007, 12, 879-889. [CrossRef] [PubMed]

41. Hsu, C.L.; Wu, C.H.; Huang, S.L.; Yen, G.C. Phenolic compounds rutin and o-coumaric acid ameliorate obesity induced by high-fat diet in rats. J. Agric. Food Chem. 2009, 57, 425-431. [CrossRef] [PubMed]

42. Cho, A.S.; Jeon, S.M.; Kim, M.J.; Yeo, J.; Seo, K.I.; Choi, M.S.; Lee, M.K. Chlorogenic acid exhibits anti-obesity property and improves lipid metabolism in high-fat diet-induced-obese mice. Food Chem. Toxicol 2010, 48, 937-943. [CrossRef] [PubMed]

43. Kim, M.; Lee, Y.J.; Jee, S.C.; Choi, I.; Sung, J.S. Anti-adipogenic effects of sesamol on human mesenchymal stem cells. Biochem. Biophys. Res. Commun. 2016, 469, 49-54. [CrossRef] [PubMed]

44. Ejaz, A.; Wu, D.; Kwan, P.; Meydani, M. Curcumin inhibits adipogenesis in 3T3-L1 adipocytes and angiogenesis and obesity in C57/BL mice. J. Nutr. 2009, 139, 919-925. [CrossRef] [PubMed]

45. Kim, C.Y.; Le, T.T.; Chen, C.; Cheng, J.X.; Kim, K.H. Curcumin inhibits adipocyte differentiation through modulation of mitotic clonal expansion. J. Nutr. Biochem. 2011, 22, 910-920. [CrossRef] [PubMed]

46. Behloul, N.; Wu, G. Genistein: A promising therapeutic agent for obesity and diabetes treatment. Eur. J. Pharmacol. 2013, 698, 31-38. [CrossRef] [PubMed] 
47. Cha, Y.S.; Park, Y.; Lee, M.; Chae, S.-W.; Park, K.; Kim, Y.; Lee, H.S. Doenjang, a korean fermented soy food, exerts antiobesity and antioxidative activities in overweight subjects with the PPAR- $\gamma 2$ C1431T polymorphism: 12-week, double-blind randomized clinical trial. J. Med. Food 2014, 17, 119-127. [CrossRef] [PubMed]

48. Yao, Y.; Li, X.B.; Zhao, W.; Zeng, Y.Y.; Shen, H.; Xiang, H.; Xiao, H. Anti-obesity effect of an isoflavone fatty acid ester on obese mice induced by high fat diet and its potential mechanism. Lipids Health Dis. 2010, 9. [CrossRef] [PubMed]

49. Ono, M.; Fujimori, K. Antiadipogenic effect of dietary apigenin through activation of AMPK in 3T3-L1 cells. J. Agric. Food Chem. 2011, 59, 13346-13352. [CrossRef] [PubMed]

50. Park, H.S.; Kim, S.H.; Kim, Y.S.; Ryu, S.Y.; Hwang, J.T.; Yang, H.J.; Kim, G.H.; Kwon, D.Y.; Kim, M.S. Luteolin inhibits adipogenic differentiation by regulating PPAR $\gamma$ activation. Biofactors 2009, 35, 373-379. [CrossRef] [PubMed]

51. He, Y.; Liu, F.; Zhang, W. Tangeritin inhibits adipogenesis by down-regulating $\mathrm{C} / \mathrm{EBP} \alpha, \mathrm{C} / \mathrm{EBP} \beta$, and PPAR $\gamma$ expression in 3T3-L1 fat cells. Genet. Mol. Res. 2015, 14, 13642-13648. [CrossRef] [PubMed]

52. Hossain, M.K.; Dayem, A.A.; Han, J.; Yin, Y.; Kim, K.; Kumar Saha, S.K.; Yang, G.M.; Choi, H.Y.; Cho, S.G. Molecular mechanisms of the anti-obesity and anti-diabetic properties of flavonoids. Int. J. Mol. Sci. 2016, 17, 569. [CrossRef] [PubMed]

53. Mohamed, G.A.; Ibrahim, S.R.; Elkhayat, E.S.; El Dine, R.S. Natural anti-obesity agents. Bull. Fac. Pharm. Cairo Univ. 2014, 52, 269-284. [CrossRef]

54. Reyes-Escogido, M.D.L.; Gonzalez-Mondragon, E.G.; Vazquez-Tzompantzi, E. Chemical and pharmacological aspects of capsaicin. Molecules 2011, 16, 1253-1270. [CrossRef] [PubMed]

55. Baboota, R.K.; Bishnoi, M.; Ambalam, P.; Kondepudi, K.K.; Sarma, S.M.; Boparai, R.K.; Podili, K. Functional food ingredients for the management of obesity and associated co-morbidities-A review. J. Funct. Foods 2013, 5, 997-1012. [CrossRef]

56. Badimon, L.; Vilahur, G.; Padro, T. Nutraceuticals and atherosclerosis: Human trials. Cardiovasc. Ther. 2010, 28, 202-215. [CrossRef] [PubMed]

57. Jin Son, M.W.; Rico, C.; Hyun Nam, S.; Young Kang, M. Influence of oryzanol and ferulic acid on the lipid metabolism and antioxidative status in high fat-fed mice. J. Clin. Biochem. Nutr. 2010, 46, 150-156. [CrossRef] [PubMed]

58. Gupta, V.K.; Tuohy, M.G.; O’Donovan, A.; Lohani, M. Biotechnology of Bioactive Compounds: Sources and Applications; Wiley-Blackwell: Chichester, UK, 2015; pp. 565-581.

59. Rideout, T.C.; Harding, S.V.; Jones, P.J. Consumption of plant sterols reduces plasma and hepatic triglycerides and modulates the expression of lipid regulatory genes and de novo lipogenesis in C57BL/6J mice. Mol. Nutr. Food Res. 2010, 54, S7-S13. [CrossRef] [PubMed]

60. Trigueros, L.; Peña, S.; Ugidos, A.; Sayas-Barberá, E.; Pérez-Álvarez, J.; Sendra, E. Food ingredients as anti-obesity agents: A review. Crit. Rev. Food Sci. Nutr. 2013, 53, 929-942. [CrossRef] [PubMed]

61. Janovskà, P.; Flachs, P.; Kazdova, L.; Kopecký, J. Anti-obesity effect of $n$-3 polyunsaturated fatty acids in mice fed high-fat diet is independent of cold-induced thermogenesis. Physiol. Res. 2013, 62, 153-161. [PubMed]

62. Poudyala, H.; Panchald, S.K.; Waandersb, J.; Wardc, L.; Browna, L. Lipid redistribution by $\alpha$-linolenic acid-rich chia seed inhibits stearoyl-CoA desaturase-1 and induces cardiac and hepatic protection in diet-induced obese rats. J. Nutr. Biochem. 2012, 23, 153-162. [CrossRef] [PubMed]

63. Slavin, J.L. Dietary fiber and body weight. Nutrition 2005, 21, 411-418. [CrossRef] [PubMed]

64. Astrup, A.; Kristensen, M.; Gregersen, N.T.; Belza, A.; Lorenzen, J.K.; Due, A.; Larsen, T.M. Can bioactive foods affect obesity? Ann. N. Y. Acad. Sci. 2010, 1190, 25-41. [CrossRef] [PubMed]

65. Papathanasopoulos, A.; Camilleri, M. Dietary fiber supplements: Effects in obesity and metabolic syndrome and relationship to gastrointestinal functions. Gastroenterology 2010, 138, 65-72. [CrossRef] [PubMed]

66. Bendtsen, L.Q.; Lorenzen, J.K.; Bendsen, N.T.; Rasmussen, C.; Astrup, A. Effect of dairy proteins on appetite, energy expenditure, body weight, and composition: A review of the evidence from controlled clinical trials. Adv. Nutr. 2013, 4, 418-438. [CrossRef] [PubMed]

67. Morell, P.; Fiszman, S. Revisiting the role of protein-induced satiation and satiety. Food Hydrocoll. 2016. [CrossRef]

68. Van der Klaauw, A.; Keogh, J.; Henning, E.; Trowse, V.; Dhillo, W.; Ghatei, M. High protein intake stimulates postprandial GLP1 and PYY release. Obesity 2013, 21, 1602-1607. [CrossRef] [PubMed] 
69. McGregor, R.A.; Poppitt, S.D. Milk protein for improved metabolic health: A review of the evidence. Nutr. Metab. 2013, 10. [CrossRef] [PubMed]

70. Zemel, M.B. The role of dairy foods in weight management. J. Am. Coll. Nutr. 2005, 24, 537S-546S. [CrossRef] [PubMed]

71. Barr, S.I. Increased dairy product or calcium intake: Is body weight or composition affected in humans? J. Nutr. 2003, 133, 245S-248S. [PubMed]

72. Delzenne, N.M.; Neyrinck, A.M.; Bäckhed, F.; Cani, P.D. Targeting gut microbiota in obesity: Effects of prebiotics and probiotics. Nat. Rev. Endocrinol. 2011, 7, 639-646. [CrossRef] [PubMed]

73. Fei, N.; Zhao, L. An opportunistic pathogen isolated from the gut of an obese human causes obesity in germfree mice. ISME J. 2013, 7, 880-884. [CrossRef] [PubMed]

74. Kadooka, Y.; Sato, M.; Imaizumi, K.; Ogawa, A.; Ikuyama, K.; Akai, Y.; Okano, M.; Kagoshima, M.; Tsuchida, T. Regulation of abdominal adiposity by probiotics (lactobacillus gasseri sbt2055) in adults with obese tendencies in a randomized controlled trial. Eur. J. Clin. Nutr. 2010, 64, 636-643. [CrossRef] [PubMed]

75. Minami, J.-I.; Kondo, S.; Yanagisawa, N.; Odamaki, T.; Xiao, J.-Z.; Abe, F.; Nakajima, S.; Hamamoto, Y.; Saitoh, S.; Shimoda, T. Oral administration of Bifidobacterium breve B-3 modifies metabolic functions in adults with obese tendencies in a randomised controlled trial. J. Nutr. Sci. 2015, 4, e17. [CrossRef] [PubMed]

76. Delzenne, N.M.; Neyrinck, A.M.; Cani, P.D. Gut microbiota and metabolic disorders: How prebiotic can work? Br. J. Nutr. 2013, 109, S81-S85. [CrossRef] [PubMed]

(C) 2016 by the authors; licensee MDPI, Basel, Switzerland. This article is an open access article distributed under the terms and conditions of the Creative Commons Attribution (CC-BY) license (http:/ / creativecommons.org/licenses/by/4.0/). 